\title{
Evidence-based guideline update: Pharmacologic treatment for episodic migraine prevention in adults
}

Report of the Quality Standards Subcommittee of the American Academy of Neurology and the American Headache Society (0口全
S.D. Silberstein, MD, FACP
S. Holland, PhD
F. Freitag, DO
D.W. Dodick, MD
C. Argoff, MD
E. Ashman, MD

Correspondence \& reprint requests to American Academy of Neurology: guidelines@aan.com

\section{See page 1346}

\section{Supplemental data at} www.neurology.org
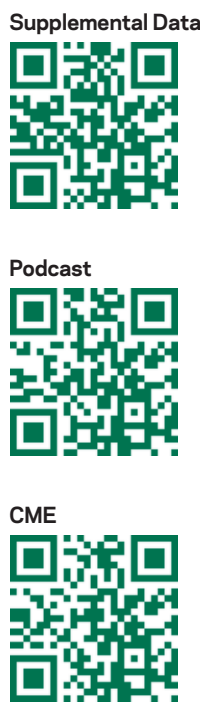

\section{ABSTRACT}

Objective: To provide updated evidence-based recommendations for the preventive treatment of migraine headache. The clinical question addressed was: What pharmacologic therapies are proven effective for migraine prevention?

Methods: The authors analyzed published studies from June 1999 to May 2009 using a structured review process to classify the evidence relative to the efficacy of various medications available in the United States for migraine prevention.

Results and Recommendations: The author panel reviewed 284 abstracts, which ultimately yielded 29 Class I or Class II articles that are reviewed herein. Divalproex sodium, sodium valproate, topiramate, metoprolol, propranolol, and timolol are effective for migraine prevention and should be offered to patients with migraine to reduce migraine attack frequency and severity (Level A). Frovatriptan is effective for prevention of menstrual migraine (Level A). Lamotrigine is ineffective for migraine prevention (Level A). Neurology ${ }^{\circledR}$ 2012;78:1337-1345

\section{GLOSSARY}

AAN = American Academy of Neurology; $\mathbf{A E}=$ adverse event; $\mathbf{C l}=$ confidence interval; $\mathbf{E R}=$ extended-release; $\mathbf{M A M}=$ menstrually associated migraine; $\mathbf{P M P}=$ perimenstrual period; $\mathbf{R C T}$ = randomized controlled trial.

Epidemiologic studies suggest approximately $38 \%$ of migraineurs need preventive therapy, but only $3 \%-13 \%$ currently use it. ${ }^{1}$ In 2000 , the American Academy of Neurology (AAN) published guidelines for migraine prevention. ${ }^{2,3}$ Since then, new clinical studies have been published on the efficacy and safety of migraine preventive therapies. This guideline seeks to assess this new evidence to answer the following clinical question: For patients with migraine, which pharmacologic therapies are proven effective for prevention, as measured by reduced migraine attack frequency, reduced number of migraine days, or reduced attack severity? This article addresses the safety and efficacy of pharmacologic therapies for migraine prevention.

Separate guidelines are available for botulinum toxin. ${ }^{4}$ The 2008 guideline included a Level B recommendation that botulinum toxin was probably ineffective for treatment of episodic migraine. A new guideline is in development. An updated guideline on nonsteroidal anti-inflammatory drugs ${ }^{5}$ and complementary alternative treatments has been approved for publication as a companion to this guideline. ${ }^{5}$

\section{DESCRIPTION OF THE ANALYTIC PROCESS}

The AAN and the American Headache Society participated in the development process. An author panel of headache and methodologic experts was assembled to review the evidence. Computerized searches of the MEDLINE, PsycINFO, and CINAHL databases identified new studies (published in English). The search strategy used the MeSH term "headache" (exploded) and a published search strategy for identifying randomized controlled trials (RCTs) published between June 1999 and May 2007. Additional MEDLINE searches revealed studies published through May

From Thomas Jefferson University (S.D.S.), Jefferson Headache Center, Philadelphia, PA; the Armstrong Atlantic State University (S.H.), Savannah, GA; Comprehensive Headache Center (F.F.), Baylor University Headache Medicine Center, Dallas, TX; Mayo Clinic (D.D.), Scottsdale, AZ; New York University School of Medicine (C.A.), Albany; and Elmendorf Air Force Base (E.A.), AK.

Appendices e-1-e-5, reference e1, and tables e-1 and e-2 are available on the Neurology ${ }^{\circledR}$ Web site at www.neurology.org.

Approved by the Quality Standards Subcommittee on February 19, 2011; by the Practice Committee on June 19, 2011; by the AHS Board of Directors on March 29, 2012; and by the AAN Board of Directors on January 27, 2012.

Study funding: This guideline was developed with financial support from the American Academy of Neurology and the American Headache Society. None of the authors received reimbursement, honoraria, or stipends for their participation in development of this guideline.

Go to Neurology.org for full disclosures. Disclosures deemed relevant by the authors, if any, are provided at the end of this article. 
Table 1 Classification of migraine preventive therapies (available in the United States)

\begin{tabular}{|c|c|c|c|c|}
\hline $\begin{array}{l}\text { Level A: Medications } \\
\text { with established } \\
\text { efficacy ( } \geq 2 \text { Class I } \\
\text { trials) }\end{array}$ & $\begin{array}{l}\text { Level B: Medications } \\
\text { are probably } \\
\text { effective ( } 1 \text { Class I } \\
\text { or } 2 \text { Class II studies) }\end{array}$ & $\begin{array}{l}\text { Level C: Medications } \\
\text { are possibly } \\
\text { effective ( } 1 \text { Class II } \\
\text { study) }\end{array}$ & $\begin{array}{l}\text { Level U: Inadequate } \\
\text { or conflicting data } \\
\text { to support or refute } \\
\text { medication use }\end{array}$ & $\begin{array}{l}\text { Other: Medications that } \\
\text { are established as } \\
\text { possibly or probably } \\
\text { ineffective }\end{array}$ \\
\hline Antiepileptic drugs & $\begin{array}{l}\text { Antidepressants/ } \\
\text { SSRI/SSNRI/TCA }\end{array}$ & $\begin{array}{l}\text { ACE inhibitors } \\
\text { Lisinopril }\end{array}$ & $\begin{array}{l}\text { Carbonic anhydrase } \\
\text { inhibitor }\end{array}$ & $\begin{array}{l}\text { Established as not } \\
\text { effective }\end{array}$ \\
\hline Divalproex sodium & Amitriptyline & $\begin{array}{l}\text { Angiotensin receptor } \\
\text { blockers }\end{array}$ & Acetazolamide & Antiepileptic drugs \\
\hline Sodium valproate & Venlafaxine & Candesartan & Antithrombotics & Lamotrigine \\
\hline Topiramate & $\beta$-Blockers & $\alpha$-Agonists & Acenocoumarol & Probably not effective \\
\hline$\beta$-Blockers & Atenolol $^{a}$ & Clonidine $^{a}$ & Coumadin & Clomipramine $^{a}$ \\
\hline Metoprolol & Nadolol $^{a}$ & Guanfacine $^{a}$ & Picotamide & Possibly not effective \\
\hline Propranolol & Triptans (MRM ${ }^{b}$ ) & Antiepileptic drugs & $\begin{array}{l}\text { Antidepressants } \\
\text { SSRI/SSNRI }\end{array}$ & Acebutolol $^{\mathrm{a}}$ \\
\hline Timolol $^{a}$ & Naratriptan ${ }^{\mathrm{b}}$ & Carbamazepine $^{a}$ & Fluvoxamine ${ }^{a}$ & Clonazepam $^{a}$ \\
\hline Triptans (MRM $\left.{ }^{b}\right)$ & Zolmitriptan ${ }^{\mathrm{b}}$ & $\beta$-Blockers & Fluoxetine & Nabumetone ${ }^{a}$ \\
\hline \multirow[t]{13}{*}{ Frovatriptan ${ }^{b}$} & & Nebivolol & Antiepileptic drugs & Oxcarbazepine \\
\hline & & Pindolol $^{\mathrm{a}}$ & Gabapentin & Telmisartan \\
\hline & & Antihistamines & TCAs & \\
\hline & & Cyproheptadine & Protriptyline ${ }^{a}$ & \\
\hline & & & $\beta$-Blockers & \\
\hline & & & Bisoprolola & \\
\hline & & & $\mathrm{Ca}++$ blockers & \\
\hline & & & Nicardipine $^{a}$ & \\
\hline & & & Nifedipine $^{a}$ & \\
\hline & & & Nimodipine & \\
\hline & & & Verapamil & \\
\hline & & & $\begin{array}{l}\text { Direct vascular } \\
\text { smooth muscle } \\
\text { relaxants }\end{array}$ & \\
\hline & & & Cyclandelate & \\
\hline
\end{tabular}

Abbreviations: ACE = angiotensin-converting-enzyme; MRM = menstrually related migraine; SSNRI = selective serotoninnorepinephrine reuptake inhibitor; SSRI = selective serotonin reuptake inhibitor; TCA = tricyclic antidepressant.

${ }^{a}$ Classification based on original guideline and new evidence not found for this report.

${ }^{b}$ For short-term prophylaxis of MRM.

2009, which were reviewed and included as supplemental articles.

Studies of pharmacologic agents available in the United States were included in the analysis if they randomized adult patients with migraine to the agent under study or a comparator drug (including placebo) and utilized masked outcome assessment. At least 2 panelists independently reviewed each study and rated it according to the AAN therapeutic classification of evidence scheme (appendix e-3 on the Neurology ${ }^{\circledR}$ Web site at www.neurology.org). Differences in ratings were resolved by author panel discussion.

ANALYSIS OF EVIDENCE The original search identified 179 articles. A supplemental search (2007-2009) yielded 105 additional articles. Of the total 284 articles, 29 were classified as Class I or Class II and are reviewed herein. Studies were excluded if they:
- Assessed the efficacy of therapeutic agents for headache other than episodic migraine in adults

- Assessed acute migraine treatment, migraine aura treatment/prevention, or nonpharmacologic treatments (e.g., behavioral approaches)

- Used quality of life measures, disability assessment, or nonstandardized outcomes as primary efficacy endpoints

- Tested the efficacy of drugs not available in the United States

Since the 2000 guideline publication, the AAN revised its evidence classification criteria to include study completion rates. Studies with completion rates below $80 \%$ were downgraded; several studies in the original guideline have thus been downgraded.

We found no new Class I or II studies published for acebutolol, atenolol, bisoprolol, carbamazepine, 
clonazepam, clonidine, clomipramine, fluvoxamine, guanfacine, nabumetone, nadolol, nicardipine, nifedipine, or protriptyline. Recommendations for these agents are based on the evidence reviewed in the original guideline (see table 1). Currently, no Class I or Class II studies exist for anticoagulants (limited Class III and IV studies were identified; table 1 includes anticoagulants).

Angiotensin receptor blockers and angiotensinconverting-enzyme inhibitors. In the 2000 guideline, there were no studies testing the efficacy of angiotensin receptor blockers or angiotensinconverting-enzyme (ACE) inhibitors for migraine prevention. Since that publication, 3 reports have been published.

Candesartan. In a Class II crossover study (12-week treatment separated by 4-week washout), the mean number of headache days was 18.5 with placebo (26.3\% reduction from baseline) vs 13.6 with candesartan $(45.6 \%$ reduction from baseline; $p=0.001){ }^{6}$ Selected secondary endpoints also favored candesartan: headache hours (139 vs 95; $p<0.001)$, migraine days (12.6 vs 9.0; $p<0.001$ ), migraine hours (92.2 vs 59.4; $p<0.001$ ), and headache severity in$\operatorname{dex}(293$ vs $191 ; p<0.001)$. No serious adverse events (AEs) occurred. The most common AEs were dizziness (31\%), "symptoms of the musculoskeletal system" (21\%), and fatigue (14\%); none occurred significantly more often than with placebo.

Lisinopril. One Class II study reported significant reduction in all 3 primary endpoints with lisinopril vs placebo (headache hours: 129 vs 162 [mean change in hours 20, confidence interval (CI) 5-36]; headache days: 19.7 vs 23.7 [20, CI 5-30]; migraine days: 14.5 vs 18.5 [21, CI 9-34]). ${ }^{7}$ AEs included cough $(26 \% ; 10 \%$ discontinued treatment due to cough), dizziness (23\%), and "tendency to faint" (10\%). No serious AEs were reported.

Telmisartan. In a single Class II placebocontrolled trial, telmisartan $80 \mathrm{mg}$ did not show a significant difference from placebo for reduction in migraine days $(-1.65$ vs -1.14$) .^{8}$

Conclusions. Lisinopril and candesartan are possibly effective for migraine prevention (1 Class II study each). Telmisartan is possibly ineffective for reducing the number of migraine days (1 negative Class II study).

Antiepileptic drugs. Divalproex. The original guideline found strong, consistent support (5 studies) for the efficacy of divalproex sodium and its corresponding compound, sodium valproate, for migraine prevention.

Since the 2000 publication, 1 double-blind, randomized, Class I placebo-controlled 12-week trial showed extended-release (ER) divalproex sodium
$500-1,000 \mathrm{mg} /$ day had a mean reduction in 4-week migraine headache rate from $4.4 /$ week (baseline) to $3.2 /$ week ( -1.2 attacks/week) in the ER divalproex sodium group and from 4.2/week to 3.6/week ( -0.6 attacks/week) in the placebo group (CI 0.2-1.2; $p=0.006) .{ }^{9}$ No significant differences were detected between groups in the number of treatment-emergent AEs.

Clinical context. In most headache trials, patients taking divalproex sodium or sodium valproate reported no more AEs than those on placebo. However, weight gain has been clinically observed with divalproex sodium long-term use. ${ }^{9,10}$ Treatment with these agents requires careful follow-up and testing because of pancreatitis, liver failure, and teratogenicity risks. ${ }^{11}$

Gabapentin. Since the 2000 publication, a Class III study $^{12}$ reported that a stable gabapentin dose (4week titration phase to $2,400 \mathrm{mg} /$ day; 8 -week maintenance phase) significantly reduced the median monthly migraine rate vs placebo on the basis of a modified intention-to-treat analysis.

Lamotrigine. The original guideline reported a single Class I lamotrigine study ${ }^{13}$ that failed to show a significant effect for migraine prevention. A second, new Class I study comparing lamotrigine $50 \mathrm{mg}$ /day with placebo or topiramate $50 \mathrm{mg} /$ day reported lamotrigine was not more effective than placebo (for both primary endpoints) and was less effective than topiramate in reducing migraine frequency and intensity. ${ }^{14}$ The primary outcome measure (responder rate: $\geq 50 \%$ monthly migraine frequency reduction) was $46 \%$ for lamotrigine vs $34 \%$ for placebo $(p=$ 0.093 , CI $0.02-0.26$ ) and $63 \%$ for topiramate vs $46 \%$ for lamotrigine $(p=0.019$, CI $0.03-0.31)$. Treatment-related AEs (rash, giddiness, sleepiness, and gastrointestinal intolerance) occurred in $10 \%$ of patients on lamotrigine.

Oxcarbazepine. One Class II trial evaluated the efficacy of oxcarbazepine $(1,200 \mathrm{mg} /$ day $)$ vs placebo. ${ }^{15}$ There was no difference between oxcarbazepine $(-1.30$ [SE 0.282]) and placebo for mean change in number of migraine attacks from baseline during the last 28 days of the double-blind 15-week treatment phase $(-1.74$ [SE 0.283]; $p=0.2274)$.

Topiramate. Four Class I studies ${ }^{14,16-18}$ and 7 Class II studies ${ }^{19-25}$ report topiramate $(50-200 \mathrm{mg} /$ day) is effective in migraine prevention.

In a Class I placebo-controlled study (mean topiramate dose $125 \mathrm{mg} /$ day [range $25-200 \mathrm{mg} /$ day]), patients given topiramate experienced a significantly lower 28-day migraine frequency vs with placebo $(3.31 \pm 1.7$ vs $3.83 \pm 2.1 ; p=0.002) .{ }^{18}$ In a second placebo-controlled Class I double-crossover study (reviewed above), topiramate was more effective than 
placebo and lamotrigine for primary efficacy measures. ${ }^{14}$ In the topiramate groups, $15 \%$ of patients experienced AEs, most commonly paresthesias, sleepiness, and gastrointestinal intolerance. The placebo group reported gastrointestinal intolerance (3\%) and anorexia (3\%).

Two additional Class I studies report topiramate is as effective as propranolol $^{16}$ or sodium valproate, ${ }^{17}$ drugs previously established as effective for migraine prevention. In the first study, subjects given topiramate $50 \mathrm{mg} /$ day had reduced mean migraine frequency (episodes/month) from baseline $(6.07 \pm 1.89$ to $1.83 \pm$ $1.39 ; p<0.001)$ at 8 weeks, decreased headache intensity VAS score from $7.1 \pm 1.45$ to $3.67 \pm 2.1(p<$ 0.001 ), and decreased headache duration from $16.37 \pm$ 7.26 hours to $6.23 \pm 5.22$ hours $(p<0.001) .{ }^{16}$ Subjects given topiramate reported paresthesias $(23 \%)$, weight loss (16\%), and somnolence (13\%). In patients treated with propranolol $80 \mathrm{mg} /$ day, mean headache frequency (episodes/month) decreased from $5.83 \pm 1.98$ to $2.2 \pm 1.67(p<0.001)$ at 8 weeks, headache intensity VAS score decreased from $6.43 \pm 1.6$ to $4.13 \pm 1.94(p<0.001)$, and headache duration decreased from $15.10 \pm 6.84$ hours to $7.27 \pm 6.46$ hours $(p<0.001)$. Although monthly headache frequency, intensity, and duration decreased in both groups, the topiramate group reported significantly greater mean reduction (topiramate frequency decrease $4.23 \pm 1.2$ vs propranolol $3.63 \pm 0.96$ [ $p=0.036$; CI $0.39-1.16]$; topiramate intensity decrease $3.43 \pm 1.38$ vs propranolol $2.3 \pm 1.2[p=0.001$; CI $0.46-1.8]$; topiramate duration decrease $10.1 \pm 4.3$ vs propranolol $7.83 \pm 4.5[p=0.048$; CI 0.17-4.6]).

In a crossover Class I trial (2-month washout between therapies) comparing topiramate $50 \mathrm{mg} / \mathrm{day}$ with sodium valproate $400 \mathrm{mg} /$ day, both groups showed improvement from baseline in headache frequency, intensity, and duration. ${ }^{17}$ Average monthly migraine frequency decreased by 1.8 times with sodium valproate (baseline $5.4 \pm 2.5$; posttreatment $3.6 \pm 2.1$; CI 1.0-2.6; $p<0.001$ ), as compared with a 3-time reduction with topiramate (baseline $5.4 \pm 2.0$; posttreatment $2.4 \pm 2.4$; CI 2.1-3.9; $p<$ $0.001)$. Headache intensity decreased by 3.7 with sodium valproate (baseline $7.7 \pm 1.2$; treatment $4.0 \pm$ 2.1; CI 2.9-4.6; $p<0.001$ ), as compared with a reduction of 3.6 with topiramate (baseline $6.9 \pm 1.2$, treatment phase $3.3 \pm 1.5$; CI 2.9-4.3; $p<0.001$ ). The average headache episode duration decreased by 13.4 hours from baseline with sodium valproate (baseline $21.3 \pm 14.6$; treatment $7.9 \pm 7.7$; CI 7.519.3; $p<0.001$ ) as compared with an 11.9-hour reduction with topiramate (baseline $17.3 \pm 8.4$; treatment $5.4 \pm 6.4$; CI 8.2-15.6; $p<0.001)$. The overall analysis of repeated-measures analysis of variance demonstrated no differences in monthly headache frequency, intensity, or duration after the first or second treatment rounds. Topiramate AEs were weight loss $(18.8 \%)$, paresthesias $(9.4 \%)$, or both (25\%). Sodium valproate AEs were weight gain (34.5\%), hair loss (3.1\%), and somnolence (3.1\%).

Results of 5 Class II studies support those of the Class I studies showing topiramate as effective for migraine prevention. ${ }^{19-25}$ Four studies demonstrated significant improvement over placebo ${ }^{19,20,23,24}$; one included an active comparator arm, suggesting equivalence of topiramate $(100,200 \mathrm{mg} /$ day $)$ and propranolol (160 mg/day). ${ }^{20}$ Two studies comparing topiramate and amitriptyline $(25-150 \mathrm{mg} /$ day) reported no difference in efficacy for primary endpoints; however, amitriptyline was associated with a significant $\mathrm{AE}$ increase, and the amitriptylinetopiramate combination suggested improvement in depression scores vs monotherapy. ${ }^{21,22}$ In one of these studies, ${ }^{21}$ the most common AEs were similar to those previously reported. One Class II placebo-controlled 24-week pilot study failed to show a difference in efficacy between topiramate $200 \mathrm{mg}$ and placebo. ${ }^{26}$

Conclusions. Divalproex sodium and sodium valproate are established as effective in migraine prevention (multiple Class I studies). Data are insufficient to determine the effectiveness of gabapentin (1 Class III study). Lamotrigine is established as ineffective for migraine prevention (2 Class I studies). Oxcarbazepine is possibly ineffective for migraine prevention (1 Class II study). Topiramate is established as effective for migraine prevention (4 Class I studies, multiple Class II studies; 1 negative Class II study). Topiramate is probably as effective for migraine prevention as propranolol (1 Class I study), sodium valproate (1 Class I study), and amitriptyline (2 Class II studies).

Antidepressants. Fluoxetine. In the original guideline, 1 Class II study ${ }^{27}$ showed fluoxetine (racemic) was significantly better than placebo for migraine prevention, but the results were not duplicated in a second study. ${ }^{28}$

Since the original guideline, a Class II study has shown fluoxetine $20 \mathrm{mg}$ /day was more effective than placebo in reducing total pain index scores (calculated as $[\mathrm{Dl} \times 1]+[\mathrm{D} 2 \times 2]+[\mathrm{D} 3 \times 3]$, where $\mathrm{D} 1$, $\mathrm{D} 2$, and D3 represent headache hours calculated in a month, with pain intensity shown by $1,2,3$ ) at 6 months. ${ }^{29}$ After the 6 months, pain index scores for the fluoxetine group decreased from 135 (baseline) to 41.3 $(\mathrm{SD} \pm 63.8 ; p=0.001)$. The placebo group pain index was 98 at baseline and 61.1 at 6 months (SD \pm 57.7 ; $p=0.07$ ); however, differences were noted between treatment groups for baseline measures. 
Venlafaxine. In a Class I study, venlafaxine XR 150 $\mathrm{mg}$ significantly reduced the number of headache days (median reduction in days: venlafaxine $150 \mathrm{mg}$ -4 days; venlafaxine $75 \mathrm{mg}-2$ days; placebo -1 day; Kruskal-Wallis $=10.306, d f=2 ; p<0.006) .{ }^{30}$ All 3 groups showed decreased headache severity and duration from baseline; no differences were observed between treatment groups for these endpoints. The most common AEs were nausea (41\%), vomiting (27\%), and drowsiness (27\%). Fourteen percent of patients receiving venlafaxine withdrew because of AEs.

A Class II trial assessed the efficacy of venlafaxine vs amitriptyline; both were effective in reducing attack frequency (venlafaxine: baseline $=4.15[\mathrm{SD} \pm$ $2.24]$ vs 12 weeks $=1.77[\mathrm{SD} \pm 1.39 ; p<0.001]$ amitriptyline: baseline $=3.27[\mathrm{SD} \pm 1.61]$ vs 12 weeks 1.54 [SD $\pm 1.54 ; p<0.001]$ ). ${ }^{31}$ Patients taking venlafaxine experienced nausea/vomiting (23\%) and tachycardia (15\%); 1 patient withdrew because of AEs. Patients taking amitriptyline reported hypersomnolence $(80 \%)$, dry mouth (69\%), and concentration difficulties (54\%).

Tricyclic antidepressants. The original guideline concluded amitriptyline was established as effective for migraine prevention; that evidence has since been downgraded to Class II (all 3 studies had $>20 \%$ dropout rates). Comparative studies of amitriptyline with topiramate $^{21,22}$ and venlafaxine ${ }^{31}$ (reviewed above) report similar efficacy at the doses tested.

Conclusions. There is conflicting Class II evidence for use of fluoxetine. Venlafaxine is probably effective for migraine prevention (1 Class I study) and is possibly as effective as amitriptyline in migraine prevention (1 Class II study). Amitriptyline is probably effective for migraine prevention (multiple Class II studies); it is probably as effective as topiramate (2 Class II studies) and possibly as effective as venlafaxine (1 Class II study) for migraine prevention.

$\boldsymbol{\beta}$-Blockers. Metoprolol. The original guideline concluded metoprolol was probably effective in migraine prevention. We reclassified these studies as Class I using the revised AAN criteria.

One new Class II study reported metoprolol (200 $\mathrm{mg} /$ day) was more effective than aspirin $(300 \mathrm{mg} /$ day) in achieving $50 \%$ migraine frequency reduction (responder rate metoprolol $=45.2 \%$; aspirin $=$ 29.6\%; mean difference 15.65; CI 4.43-26.88)..$^{32}$ Attack frequencies (attacks/month) at placebo run-in and week 20 are 3.36 to 2.37 , respectively, for aspirin and 3.55 to 1.82 , respectively, for metoprolol. No significant AEs were reported.

A small Class II study reported metoprolol (47.5$142.5 \mathrm{mg} /$ day) had similar efficacy to nebivolol 5 $\mathrm{mg} /$ day for migraine prevention (assessed by a decrease in mean migraine attacks). ${ }^{33}$

Propranolol. The original guideline concluded propranolol was established as effective for migraine prevention.

In a Class II study, propranolol (80 mg/day) was more effective than placebo and as effective as cyproheptadine ( $4 \mathrm{mg} / \mathrm{day}$ ) in reducing migraine frequency, duration, and attack severity. ${ }^{34}$ The difference in attack frequency reduction was significant between treatments: propranolol $-2.85 \pm 0.2$ (SEM) vs cyproheptadine $-3.09 \pm 0.31$ vs combination $3.12 \pm 0.1$ vs placebo $-1.77 \pm 0.44$ (all $p<$ 0.05 vs placebo). For attack frequency reduction, combination therapy was more effective than monotherapy $(p<0.05)$. AEs were drowsiness, sleep disturbance, weight gain, fatigue, and dry mouth; percentages of patients affected were not reported.

Conclusions. Metoprolol is established as effective for migraine prevention (2 Class I studies) and is possibly as effective as nebivolol or aspirin for migraine prevention (1 Class II study each). Propranolol is established as effective for migraine prevention (multiple Class I studies) and is possibly as effective as cyproheptadine for migraine prevention (1 Class II study).

Calcium-channel blockers. The original guideline concluded that verapamil and nimodipine were probably effective for migraine prevention. The original studies on verapamil and nimodipine were found to have conflicting Class III evidence on the basis of current classification criteria and were downgraded accordingly, yielding Level $\mathrm{U}$ recommendations.

Conclusions. Data from older studies regarding verapamil and nimodipine are insufficient when current AAN classification criteria are applied.

Direct vascular smooth muscle relaxants. The original guideline concluded cyclandelate was probably effective for migraine prevention.

Cyclandelate. Two new Class II studies reported conflicting results. The first study showed cyclandelate to be no more effective than placebo in reducing migraine days, attacks, or duration. ${ }^{35}$ The second study (smaller, underpowered; $\mathrm{n}=25$ ) found cyclandelate significantly reduced the number of migraine days and duration (assessed using a contingent negative variation measure). ${ }^{36}$

Conclusions. The efficacy of cyclandelate is unknown (conflicting Class II studies).

Triptans. Since the original guideline, new Class I studies have assessed the efficacy of frovatriptan, ${ }^{37,38}$ naratriptan, ${ }^{39}$ and zolmitriptan ${ }^{40}$ for short-term prevention of menstrually associated migraine (MAM).

Frovatriptan. Frovatriptan $2.5 \mathrm{mg} \mathrm{BID} / \mathrm{qd}$ was more effective than placebo in reducing migraine fre- 
quency. ${ }^{37}$ The mean number of headache-free perimenstrual periods (PMPs) per patient (primary endpoint) was higher in the 2 frovatriptan groups (2.5 $\mathrm{mg} \mathrm{qd}=0.69$ [SD $\pm 0.92 ;$ CI $1.14-2.73 ; p=$ 0.0091 ] vs $2.5 \mathrm{mg} \mathrm{BID}=0.92$ [SD 1.03; CI 1.84$4.28 ; p<0.0001]$ vs placebo $=0.42[\mathrm{SD} \pm 0.78]$ ), representing 64\% (2.5 mg/day) and 119\% (5 mg/ day) increases in the mean number of headache-free PMPs per patient over placebo. A second Class I study $^{38}$ also reports the MAM headache incidence during the 6-day PMP was 67\% for placebo, $52 \%$ for frovatriptan $2.5 \mathrm{mg} \mathrm{QD}$ ( $p<0.0001$ vs placebo), and $41 \%$ for frovatriptan $2.5 \mathrm{mg}$ BID $(p<0.0001$ vs placebo; $p<0.0001$ vs $\mathrm{QD}$ regimen). The $\mathrm{AE}$ incidence and type for both regimens were similar to those for placebo. The overall AE incidence for frovatriptan was $4.1 \%$ (2.5 mg BID) and $2.7 \%(2.5 \mathrm{mg}$ qd) higher than during placebo treatment.

Naratriptan. In a Class I study, $1 \mathrm{mg}$ BID (given for 5 days, starting 2 days before menses onset) reduced the number of perimenstrual migraine attacks and migraine days. ${ }^{39}$ Patients treated with naratriptan $1 \mathrm{mg}$ experienced more headache-free PMPs than those on placebo $(50 \%$ vs $25 \%, p=$ 0.003). Naratriptan $1 \mathrm{mg}$ reduced the number of MAMs (2.0 vs 4.0, $p<0.05$ ) and MAM days (4.2 vs 7.0, $p<0.01)$ vs placebo. The AE incidence and severity were similar to those of placebo; $<10 \%$ of patients experienced dizziness, chest pain, or malaise.

Zolmitriptan. One Class I study reported the efficacy of zolmitriptan $2.5 \mathrm{BID} / \mathrm{TID}$ vs placebo. Both zolmitriptan regimens demonstrated superior efficacy vs placebo: the proportion of patients with a $\geq 50 \%$ MAM attack frequency reduction (zolmitriptan $2.5 \mathrm{mg}$ TID [58.6\%], $p=0.0007$ vs placebo; zolmitriptan $2.5 \mathrm{mg}$ BID [54.7\%], $p=0.002$ vs placebo; placebo $37.8 \%) .{ }^{40}$ AEs were considered possibly treatment-related in 28 patients $(33.3 \%)$ in the zolmitriptan $2.5 \mathrm{mg}$ TID group, 29 (36.3\%) in the zolmitriptan $2.5 \mathrm{mg}$ BID group, and 18 (22.0\%) in the placebo group. The most common AEs were asthenia, headache, dizziness, and nausea.

Conclusions. Frovatriptan is established as effective for the short-term prevention of MAMs (2 Class I studies). Zolmitriptan and naratriptan are probably effective for the short-term prevention of MAMs (1 Class I study each). The utility of these agents in receiving a separate indication for pure menstrual migraine is currently being deliberated by US regulatory authorities.

Other agents. Since the original guideline, additional studies have been identified that assess the efficacy of a carbonic anhydrase inhibitor and a neurokinin inhibitor for migraine prevention.

Carbonic anhydrase inhibitor. In a single Class II study, acetazolamide $250 \mathrm{mg}$ BID was no more effective than placebo in reducing migraine frequency, duration, and severity. ${ }^{\text {e1 }}$ This trial ( $\mathrm{n}=$ 53) was stopped prematurely because of a high number of withdrawals (34\%), primarily due to acetazolamide-associated AEs, including paresthesias and asthenia.

Conclusions. The efficacy of acetazolamide is unknown at this time (1 Class II study terminated early).

RECOMMENDATIONS Level A. The following medications are established as effective and should be offered for migraine prevention:

- Antiepileptic drugs (AEDs): divalproex sodium, sodium valproate, topiramate

- $\beta$-Blockers: metoprolol, propranolol, timolol

- Triptans: frovatriptan for short-term MAMs prevention

Level B. The following medications are probably effective and should be considered for migraine prevention:

- Antidepressants: amitriptyline, venlafaxine

- $\beta$-Blockers: atenolol, nadolol

- Triptans: naratriptan, zolmitriptan for shortterm MAMs prevention

Level C. The following medications are possibly effective and may be considered for migraine prevention:

- ACE inhibitors: lisinopril

- Angiotensin receptor blockers: candesartan

- $\alpha$-Agonists: clonidine, guanfacine

- AEDs: carbamazepine

- $\beta$-Blockers: nebivolol, pindolol

Level U. Evidence is conflicting or inadequate to support or refute the use of the following medications for migraine prevention:

- AEDs: gabapentin

- Antidepressants

- Selective serotonin reuptake inhibitor/selective serotonin-norepinephrine reuptake inhibitors: fluoxetine, fluvoxamine

- Tricyclics: protriptyline

- Antithrombotics: acenocoumarol, Coumadin, picotamide

- $\beta$-Blockers: bisoprolol

- Calcium-channel blockers: nicardipine, nifedipine, nimodipine, verapamil

- Acetazolamide

- Cyclandelate

Level A negative. The following medication is established as ineffective and should not be offered for migraine prevention:

- Lamotrigine 
Level B negative. The following medication is probably ineffective and should not be considered for migraine prevention:

- Clomipramine

Level C negative. The following medications are possibly ineffective and may not be considered for migraine prevention:

- Acebutolol

- Clonazepam

- Nabumetone

- Oxcarbazepine

- Telmisartan

CLINICAL CONTEXT Evidence to support pharmacologic treatment strategies for migraine prevention indicates which treatments might be effective but is insufficient to establish how to choose an optimal therapy. Consequently, although Level A recommendations can be made for pharmacologic migraine prevention, similar evidence is unavailable to help the practitioner choose one therapy over another. Treatment regimens, therefore, need to be designed case by case, which may include complex or even nontraditional approaches. Moreover, decision-making must remain with the physician and the patient to determine the optimal therapy, accounting for efficacy, AEs, coexisting/comorbid conditions, and personal considerations. Often trial and error is needed.

Evidence is also unavailable for making broad-range comparisons among multiple agents within a single class; such evidence would provide a more comprehensive understanding of relative efficacy and tolerability profiles across a broader range of therapeutic agents. Studies are needed that specifically evaluate when preventive therapy is warranted and how medications should be titrated. Table e-1 lists some specific consensus-based clinical circumstances wherein considering preventive therapy would be reasonable. A shortcoming of migraine prevention clinical studies is the relatively brief treatment duration (often only 12-16 weeks). Long-term assessment of the efficacy and safety of migraine preventive treatments is needed. Additionally, overall cost is a consideration when prescribing medications; cost may influence compliance, especially long-term.

It seems reasonable that a clinician be mindful of comorbid and coexistent conditions in patients with migraine, to maximize potential treatment efficacy and minimize AE risk. Table e-2 identifies which therapies to consider or avoid when common migraine coexisting conditions are present. Because migraine is frequent in women of childbearing age, the potential for adverse fetal effects related to migraine prevention strategies is particularly concerning.
Evidence from the 2 Class I frovatriptan studies meets the AAN threshold for a Level A recommendation for short-term use to prevent menstrual migraine (reduction in MAM headache incidence by $26 \%$ on $2.5 \mathrm{mg}$ BID). However, the Food and Drug Administration questions whether the benefit demonstrated is clinically meaningful and has not approved frovatriptan for this indication.

RECOMMENDATIONS FOR FUTURE RESEARCH Although many preventive therapies reviewed herein are rated as Level $\mathrm{C}$ or $\mathrm{U}$ on the basis of the quality of evidence available, for some treatments extensive clinical experience supports a possible role in migraine prevention. Many of the older approaches to treating episodic migraine lack the financial justification for high-quality clinical study because they are not currently patentable drugs or otherwise do not promise a financial return for the cost of a major study. Until such treatments can be accurately studied, practitioners are cautioned not to discount these agents because Class I prospective clinical studies are lacking. A case-by-case evaluation of these agents as treatment options is prudent. Future directions should include validating these initial clinical observations in scientifically sound RCTs.

\section{AUTHOR CONTRIBUTIONS}

Dr. Silberstein: manuscript preparation, drafting/revising the manuscript, study concept or design, analysis or interpretation of data, acquisition of data, study supervision. Dr. Holland: drafting/revising the manuscript, study concept or design, analysis or interpretation of data. Dr. Freitag: drafting/revising the manuscript, analysis or interpretation of data, acquisition of data. Dr. Dodick: drafting/revising the manuscript, study concept or design, analysis or interpretation of data. Dr. Argoff: drafting/ revising the manuscript, study concept or design, analysis or interpretation of data. Dr. Ashman: drafting/revising the manuscript, analysis or interpretation of data.

\section{DISCLOSURE}

Dr. Silberstein is on the advisory panel of and receives honoraria from AGA, Allergan, Amgen, Capnia, Coherex, Colucid, Cydex, GlaxoSmithKline, Lilly, MAP, Medtronic, Merck, Minster, Neuralieve, NINDS, NuPathe, Pfizer, St. Jude Medical, and Valeant. He is on the speakers' bureau of and receives honoraria from Endo Pharmaceuticals, GlaxoSmithKline, and Merck. He serves as a consultant for and receives honoraria from Amgen and Novartis. His employer receives research support from AGA, Allergan, Boston Scientific, Capnia, Coherex, Endo Pharmaceuticals, GlaxoSmithKline, Lilly, MAP, Medtronic, Merck, NINDS, NuPathe, St. Jude Medical, and Valeant Pharmaceuticals. Dr. Holland (formerly Dr. Pearlman) receives consulting income from Map Pharmaceuticals and the American Headache Society and research support from Albert Einstein College of Medicine. Dr. Freitag has served on the scientific advisory boards of Zogenix Pharmaceuticals, Allergan Pharmaceuticals, Nautilus, MAP Pharmaceuticals, and Nupathe; has received travel expenses and or honoraria from GlaxoSmithKline, Zogenix, Merck, Nautilus, Allergan, Diamond Headache Clinic Research and Educational Foundation (not for profit), and the American Headache Society (travel). Dr. Freitag is a member of the Board of Directors of the National Headache Foundation. Dr. Dodick, within the past 3 years, serves on advisory boards and has consulted for Allergan, Alder, Pfizer, Merck, Coherex, Ferring, Neurocore, Neuralieve, Neuraxon, NuPathe Inc., MAP, SmithKlineBeecham, Boston Scientific, Medtronic, Inc., Nautilus, Eli Lilly \& Company, No- 
vartis, Colucid, GlaxoSmithKline, Autonomic Technologies, MAP Pharmaceuticals, Inc., Zogenix, Inc., Impax Laboratories, Inc., Bristol Myers Squibb, Nevro Corporation, Atlas, Arteaus, and Alder Pharmaceuticals. Within the past 3 years, Dr. Dodick has received funding for travel, speaking, or editorial activities from CogniMed, Scientiae, Intramed, SAGE Publishing, Lippincott Williams \& Wilkins, Oxford University Press, Cambridge University Press, Miller Medical, Annenberg for Health Sciences; he serves as Editor-in-Chief and on the editorial boards of The Neurologist, Lancet Neurology, and Postgraduate Medicine; and has served as Editor-in-Chief of Headache Currents and as an Associate Editor of Headache; he receives publishing royalties for Wolff's Headache, 8th edition (Oxford University Press, 2009) and Handbook of Headache (Cambridge University Press, 2010). Within the past 3 years, Dr. Dodick has received research grant support from Advanced Neurostimulation Systems, Boston Scientific, St Jude Medical, Inc., Medtronic, NINDS/NIH, Mayo Clinic. Dr. Argoff has served on a scientific advisory board for the Department of Defense and DSMB for the NIH; has received funding for travel and/or speaking and/or has served on a speakers' bureau for Pfizer (King), Janssen (Pricara), Millennium Laboratories, Neurogesx, Forest Laboratories, Eli Lilly, Covidien, and Endo Pharmaceuticals; has received research support from Endo Pharmaceuticals, Forest Laboratories, Eli Lilly, Neurogesx, Pfizer, and SBRT funded by the NIH; and has received stock/stock options from Pfizer. Dr. Ashman is the Level of Evidence editor for Neurology and serves on the AAN Guideline Development Subcommittee. He reports no other disclosures. Full disclosures were provided at the time of Board approval. Go to Neurology.org for full disclosures.

\section{DISCLAIMER}

This statement is provided as an educational service of the American Academy of Neurology and the American Headache Society. It is based on as assessment of current scientific and clinical information. It is not intended to include all possible proper methods of care for a particular neurologic problem or all legitimate criteria for choosing to use a specific procedure. Neither is it intended to exclude any reasonable alternative methodologies. The AAN and the AHS recognize that specific patient care decisions are the prerogative of the patient and the physician caring for the patient, based on all of the circumstances involved. The clinical context section is made available in order to place the evidence-based guideline(s) into perspective with current practice habits and challenges. No formal practice recommendations should be inferred.

\section{CONFLICT OF INTEREST}

The American Academy of Neurology and the American Headache Society are committed to producing independent, critical and truthful clinical practice guidelines (CPGs). Significant efforts are made to minimize the potential for conflicts of interest to influence the recommendations of this CPG. To the extent possible, the AAN and AHS keep separate those who have a financial stake in the success or failure of the products appraised in the CPGs and the developers of the guidelines. Conflict of interest forms were obtained from all authors and reviewed by an oversight committee prior to project initiation. AAN and AHS limit the participation of authors with substantial conflicts of interest. The AAN and AHS forbid commercial participation in, or funding of, guideline projects. Drafts of the guidelines have been reviewed by at least three AAN and AHS committees, a network of neurologists, Neurology peer reviewers, and representatives from related fields. The AAN Guideline Author Conflict of Interest Policy can be viewed at www.aan.com.

Received June 27, 2011. Accepted in final form January 25, 2012.

\section{REFERENCES}

1. Lipton RB, Bigal ME, Diamond M, Freitag F, Reed ML, Stewart WF; The American Migraine Prevalence and Prevention Advisory Group. Migraine prevalence, disease burden, and the need for preventive therapy. Neurology 2007; 68:343-349.
2. Ramadan NM, Silberstein SD, Freitag FG, Gilbert TT, Frishberg BM. Evidence-based guidelines for migraine headache in the primary care setting: pharmacological management for prevention of migraine. Available at: http://www.aan.com/professionals/practice/pdfs/gl0090. pdf. Accessed April 10, 1010.

3. Silberstein SD. Practice parameter: evidence-based guidelines for migraine headache (an evidence-based review): report of the Quality Standards Subcommittee of the American Academy of Neurology. Neurology 2000;55: 754-762.

4. Naumann M, So Y, Argoff C, et al. Assessment: Botulinum neurotoxin in the treatment of autonomic disorders and pain (an evidence-based review): report of the Therapeutics and Technology Subcommittee of the American Academy of Neurology. Neurology 2008;70:1707-1714.

5. Holland S, Silberstein SD, Freitag F, Dodick DW, Argoff C, Ashman E. Evidence-based guideline update: NSAIDs and other complementary treatments for episodic migraine prevention in adults: report of the Quality Standards Subcommittee of the American Academy of Neurology and the American Headache Society. Neurology 2012;78: 1346-1353.

6. Tronvik E, Stovner LJ, Helde G, Sant T, Bovim G. Prophylactic treatment of migraine with an angiotensin II receptor blocker: a randomized controlled trial. JAMA 2003; 289:65-69.

7. Schrader H, Stovner LJ, Helde G, Sand T, Bovim G. Prophylactic treatment of migraine with angiotensin converting enzyme inhibitor (lisinopril): randomised, placebo controlled, crossover study. BMJ 2001;322:19-22.

8. Diener HC, Gendolla A, Feuersenger A, et al. Telmisartan in migraine prophylaxis: a randomized, placebo-controlled trial. Cephalalgia 2009;29:921-927.

9. Freitag FG, Collins SD, Carlson HA, et al. A randomized trial of divalproex sodium extended-release tablets in migraine prophylaxis. Neurology 2002;58:1652-1659.

10. Silberstein SD, Collins SD. Safety of divalproex sodium in migraine prophylaxis: an open-label, long-term study: long-term safety of Depakote in Headache Prophylaxis Study Group. Headache 1999;39:633-643.

11. Harden CL, Meador KJ, Pennell PB, et al; American Academy of Neurology; American Epilepsy Society. Practice parameter update: management issues for women with epilepsy-focus on pregnancy (an evidence-based review): teratogenesis and perinatal outcomes: report of the Quality Standards Subcommittee and Therapeutics and Technology Assessment Subcommittee of the American Academy of Neurology and American Epilepsy Society. Neurology 2009;73:133-141.

12. Mathew NT, Rapoport A, Saper J, et al. Efficacy of gabapentin in migraine prophylaxis. Headache 2001;41:119128.

13. Steiner TJ, Findley LJ, Yuen AW. Lamotrigine versus placebo in the prophylaxis of migraine with and without aura. Cephalalgia 1997;17:109-112.

14. Gupta P, Singh S, Goyal V, Shukla G, Behari M. Lowdose topiramate versus lamotrigine in migraine prophylaxis (the Lotolamp study). Headache 2007;47:402-412.

15. Silberstein SD, Saper J, Berenson F, Somogyi M, McCague MA, D'Souza JD. Oxcarbazepine in migraine headache: a double-blind, randomized, placebo-controlled study. Neurology 2008;70:548-555. 
16. Ashtari F, Shaygannejad V, Akbari M. A double-blind, randomized trial of low-dose topiramate vs propranolol in migraine prophylaxis. Acta Neurol Scand 2008;118:301305.

17. Shaygannejad V, Janghorbani M, Ghorbani A, Ashtary F, Zakizade N, Nasr V. Comparison of the effect of topiramate and sodium valproate in migraine prevention: a randomized blinded crossover study. Headache 2006; 46:642-648.

18. Storey JR, Calder CS, Hart DE, Potter DL. Topiramate in migraine prevention: a double-blind, placebo-controlled study. Headache 2001;41:968-975.

19. Brandes JL, Saper JR, Diamond M, et al; MIGR-002 Study Group. Topiramate for migraine prevention: a randomized controlled trial. JAMA 2004;291:965-973.

20. Diener HC, Matias-Guiu J, Hartung E, et al. Topiramate in migraine prophylaxis-results from a placebo-controlled trial with propranolol as an active control. J Neurol 2004; 251:943-950.

21. Dodick DW, Freitag F, Banks J, et al; CAPSS-277 Investigator Group. Topiramate versus amitriptyline in migraine prevention: a 26-wk, multicenter, randomized, doubleblind, double-dummy, parallel-group noninferiority trial in adult migraineurs. Clin Ther 2009;31:542-559.

22. Keskinbora K, Aydinli I. A double-blind randomized controlled trial of topiramate and amitriptyline either alone or in combination for the prevention of migraine. Clin Neurol Neurosurg 2008;110:979-984.

23. Mei D, Capuano A, Vollono C, et al. Topiramate in migraine prophylaxis: a randomised double-blind versus placebo study. Neurol Sci 2004;25:245-250.

24. Silberstein SD, Neto W, Schmitt J, Jacobs D; MIGR-001 Study Group. Topiramate in migraine prevention: results of a large controlled trial. Arch Neurol 2004;61:490-495.

25. Millán-Guerrero RO, Isais-Millán R, Barreto-Vizcaíno S, et al. Subcutaneous histamine versus topiramate in migraine prophylaxis: a double-blind study. Eur Neurol 2008;59:237-242.

26. Silberstein SD, Hulihan J, Karim MR, et al. Efficacy and tolerability of topiramate $200 \mathrm{mg} / \mathrm{d}$ in the prevention of migraine with/without aura in adults: a randomized, placebo-controlled, double-blind, 12-week pilot study. Clin Ther 2006;28:1002-1011.

27. Adly C, Straumanis J, Chesson A. Fluoxetine prophylaxis of migraine. Headache 1992;32:101-104.

28. Saper JR, Silberstein SD, Lake AE III, Winters ME. Double-blind trial of fluoxetine: chronic daily headache and migraine. Headache 1994;34:497-502.
29. d'Amato CC, Pizza V, Marmolo T, Giordano E, Alfano V, Nasta A. Fluoxetine for migraine prophylaxis: a doubleblind trial. Headache 1999;39:716-719.

30. Ozyalcin SN, Talu GK, Kiziltan E, Yucel B, Ertas M, Disci $R$. The efficacy and safety of venlafaxine in the prophylaxis of migraine. Headache 2005;45:144-152.

31. Bulut S, Berilgen MS, Baran A, Tekatas A, Atmaca M, Mungen B. Venlafaxine versus amitriptyline in the prophylactic treatment of migraine: randomized, doubleblind, crossover study. Clin Neurol Neurosurg 2004;107: $44-48$.

32. Diener HC, Hartung E, Chrubasik J, et al. A comparative study of oral acetylsalicylic acid and metoprolol for the prophylactic treatment of migraine: a randomized, controlled, double-blind, parallel group phase III study. Cephalalgia 2001;21:120-128.

33. Schellenberg R, Lichtenthal A, Wöhling H, Graf C, Brixius K. Nebivolol and metoprolol for treating migraine: an advance on beta-blocker treatment? Headache 2008; 48 : $118-125$.

34. Rao BS, Das DG, Taraknath VR, Sarma Y. A double blind controlled study of propranolol and cyproheptadine in migraine prophylaxis. Neurol India 2000;48:223-226.

35. Diener HC, Krupp P, Schmitt T, Steitz G, Milde K, Freytag S; on behalf of the Study Group. Cyclandelate in the prophylaxis of migraine: a placebo-controlled study. Cephalalgia 2001;21:66-70.

36. Siniatchkin M, Gerber WD, Vein A. Clinical efficacy and central mechanisms of cyclandelate in migraine: a doubleblind placebo-controlled study. Funct Neurol 1998;13: 47-56.

37. Silberstein SD, Elkind AH, Schreiber C, Keywood C. A randomized trial of frovatriptan for the intermittent prevention of menstrual migraine. Neurology 2004;63:261269.

38. Brandes JL, Poole A, Kallela M, et al. Short-term frovatriptan for the prevention of difficult-to-treat menstrual migraine attacks. Cephalalgia 2009;29:1133-1148.

39. Newman L, Mannix LK, Landy S, et al. Naratriptan as short-term prophylaxis of menstrually associated migraine: a randomized, double-blind, placebo-controlled study. Headache 2001;41:248-256.

40. Tuchman MM, Hee A, Emeribe U, Silberstein S. Oral zolmitriptan in the short-term prevention of menstrual migraine: a randomized, placebo-controlled study. CNS Drugs 2008;22:877-886. 


\section{Neurology}

Evidence-based guideline update: Pharmacologic treatment for episodic migraine prevention in adults: Report of the Quality Standards Subcommittee of the American Academy of Neurology and the American Headache Society

S.D. Silberstein, S. Holland, F. Freitag, et al.

Neurology 2012;78;1337-1345

DOI 10.1212/WNL.0b013e3182535d20

This information is current as of April 23, 2012

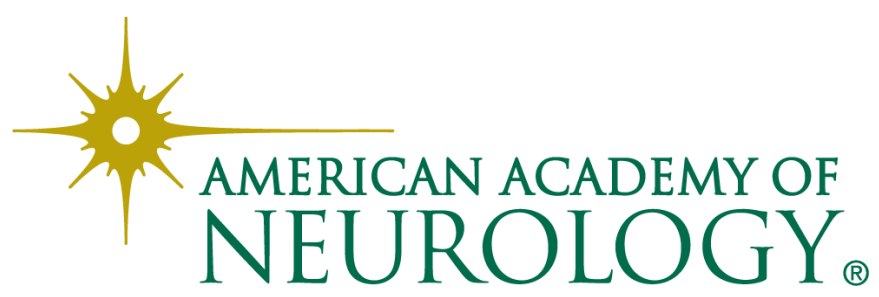




\section{Updated Information \& Services}

\section{Supplementary Material}

\section{References}

Citations

Subspecialty Collections

\section{Errata}

\section{Permissions \& Licensing}

\section{Reprints}

including high resolution figures, can be found at: http://n.neurology.org/content/78/17/1337.full

Supplementary material can be found at: http://n.neurology.org/content/suppl/2012/04/22/78.17.1337.DC1 http://n.neurology.org/content/supp1/2012/04/22/78.17.1337.DC2 http://n.neurology.org/content/suppl/2012/12/03/78.17.1337.DC3 http://n.neurology.org/content/suppl/2013/01/03/78.17.1337.DC4

This article cites 39 articles, 9 of which you can access for free at: http://n.neurology.org/content/78/17/1337.full\#ref-list-1

This article has been cited by 11 HighWire-hosted articles: http://n.neurology.org/content/78/17/1337.full\#\#otherarticles

This article, along with others on similar topics, appears in the following collection(s):

\section{Migraine}

http://n.neurology.org/cgi/collection/migraine

Palliation pain

http://n.neurology.org/cgi/collection/palliation_pain

An erratum has been published regarding this article. Please see next page or: /content/80/9/871.full.pdf

Information about reproducing this article in parts (figures,tables) or in its entirety can be found online at:

http://www.neurology.org/about/about_the_journal\#permissions

Information about ordering reprints can be found online: http://n.neurology.org/subscribers/advertise

Neurology ${ }^{\circledR}$ is the official journal of the American Academy of Neurology. Published continuously since 1951, it is now a weekly with 48 issues per year. Copyright Copyright (? 2012 by AAN Enterprises, Inc.. All rights reserved. Print ISSN: 0028-3878. Online ISSN: 1526-632X.

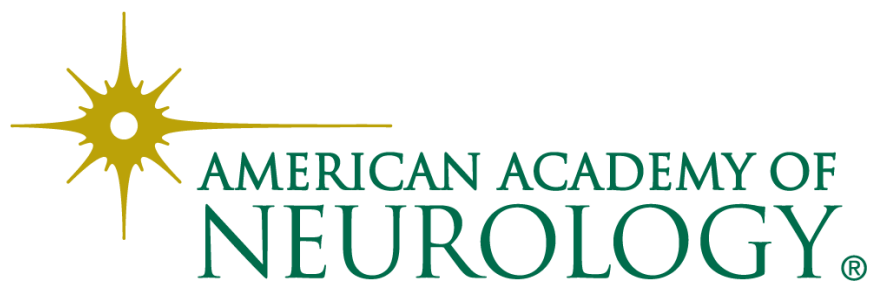




\section{CORRECTION}

Evidence-based guideline update: Pharmacologic treatment for episodic migraine prevention in adults: Report of the Quality Standards Subcommittee of the American Academy of Neurology and the American Headache Society

In the special article "Evidence-based guideline update: Pharmacologic treatment for episodic migraine prevention in adults: Report of the Quality Standards Subcommittee of the American Academy of Neurology and the American Headache Society" by S.D. Silberstein et al. (Neurology 2012;78:1337-1345), there are errors in table 1 and the text on page 1342. Due to changes in the AAN's LOE classification criteria, pindolol and clonidine should have been labeled as having Level U recommendations and nicardipine should have been listed as having a Level $\mathrm{C}$ recommendation. These changes are based on studies cited in the original 2001 guideline; no new studies were found in the literature search for the 2012 update. Please see the corrected table below. The authors regret the errors.

Table 1 Classification of migraine preventive therapies (available in the United States)

\begin{tabular}{|c|c|c|c|c|}
\hline $\begin{array}{l}\text { Level A: Medications } \\
\text { with established } \\
\text { efficacy ( } \geq 2 \text { Class I } \\
\text { trials) }\end{array}$ & $\begin{array}{l}\text { Level B: Medications } \\
\text { are probably } \\
\text { effective ( } 1 \text { Class I } \\
\text { or } 2 \text { Class II studies) }\end{array}$ & $\begin{array}{l}\text { Level C: Medications } \\
\text { are possibly } \\
\text { effective ( } 1 \text { Class II } \\
\text { study) }\end{array}$ & $\begin{array}{l}\text { Level U: Inadequate } \\
\text { or conflicting data } \\
\text { to support or refute } \\
\text { medication use }\end{array}$ & $\begin{array}{l}\text { Other: Medications } \\
\text { that are established } \\
\text { as ineffective, } \\
\text { probably ineffective, } \\
\text { or possibly } \\
\text { ineffective }\end{array}$ \\
\hline Antiepileptic drugs & $\begin{array}{l}\text { Antidepressants/ } \\
\text { SSRI/SSNRI/TCA }\end{array}$ & ACE inhibitors & $\alpha$-Agonists & $\begin{array}{l}\text { Established as } \\
\text { ineffective }\end{array}$ \\
\hline Divalproex sodium & Amitriptyline & Lisinopril & Clonidine $^{a}$ & Lamotrigine \\
\hline Sodium valproate & Venlafaxine & $\alpha$-Agonists & $\begin{array}{l}\text { Antidepressants/ } \\
\text { SSRI/SSNRI }\end{array}$ & Probably ineffective \\
\hline Topiramate & $\beta$-Blockers & Guanfacine $^{a}$ & Fluoxetine & Clomipramine $^{a}$ \\
\hline$\beta$-Blockers & Atenolol $^{a}$ & $\begin{array}{l}\text { Angiotensin receptor } \\
\text { blockers }\end{array}$ & Fluvoxamine $^{a}$ & Possibly ineffective \\
\hline Metoprolol & Nadolol $^{\mathrm{a}}$ & Candesartan & Antiepileptic drugs & Acebutolol $^{\mathrm{a}}$ \\
\hline Propranolol & Triptans (MRM $\left.{ }^{b}\right)$ & Antiepileptic drugs & Gabapentin & Clonazepam $^{a}$ \\
\hline Timolol $^{a}$ & Naratriptan ${ }^{\mathrm{b}}$ & Carbamazepine $^{a}$ & Antithrombotics & Nabumetone $^{a}$ \\
\hline Triptans (MRM ${ }^{\mathrm{b}}$ ) & Zolmitriptan ${ }^{b}$ & Antihistamines & Acenocoumarol & Oxcarbazepine \\
\hline \multirow[t]{15}{*}{ Frovatriptan ${ }^{\mathrm{b}}$} & & Cyproheptadine & Coumadin & Telmisartan \\
\hline & & $\beta$-Blockers & Picotamide & \\
\hline & & Nebivolol & $\beta$-Blockers & \\
\hline & & $\mathrm{Ca}++$ blockers & Bisoprolol $^{a}$ & \\
\hline & & Nicardipine $^{a}$ & Pindolol $^{a}$ & \\
\hline & & & $\mathrm{Ca}++$ blockers & \\
\hline & & & Nifedipine $^{a}$ & \\
\hline & & & Nimodipine & \\
\hline & & & Verapamil & \\
\hline & & & $\begin{array}{l}\text { Carbonic anhydrase } \\
\text { inhibitor }\end{array}$ & \\
\hline & & & Acetazolamide & \\
\hline & & & $\begin{array}{l}\text { Direct vascular } \\
\text { smooth muscle } \\
\text { relaxants }\end{array}$ & \\
\hline & & & Cyclandelate & \\
\hline & & & TCAs & \\
\hline & & & Protriptyline ${ }^{a}$ & \\
\hline
\end{tabular}

Abbreviations: $\mathrm{ACE}$ = angiotensin-converting-enzyme; $\mathrm{Ca}++$ blockers = calcium channel blockers; MRM = menstrually related migraine; SSNRI = selective serotonin-norepinephrine reuptake inhibitor; SSRI = selective serotonin reuptake inhibitor; TCA = tricyclic antidepressant.

${ }^{a}$ Classification based on original guideline and new evidence not found for this report.

${ }^{\mathrm{b}}$ For short-term prophylaxis of MRM. 